\title{
Renal agenesis
}

INSERM

\section{Source}

INSERM. (1999). Orphanet: an online rare disease and orphan drug data base. Renal agenesis. ORPHA:411709

Renal agenesis (RA) is a form of renal tract malformation characterized by the complete absence of development of one or both kidneys (unilateral RA or bilateral RA respectively; see these terms), accompanied by absent ureter(s). 